\title{
Sheep 6-phosphogluconate dehydrogenase
}

\author{
Revised protein sequence based upon the sequences of cDNA clones obtained \\ with the polymerase chain reaction
}

\author{
Donald O’N. SOMERS, ${ }^{*} § \S$ Simon M. MEDD, ${ }^{*}$ John E. WALKER ${ }^{*} \ddagger$ and Margaret J. ADAMS $\dagger$ \\ *M.R.C. Laboratory of Molecular Biology, Hills Road, Cambridge CB2 2QH, U.K., \\ and †Laboratory of Molecular Biophysics, The Rex Richards Building, South Parks Road, Oxford OX1 3QU, U.K.
}

\begin{abstract}
Sheep liver 6-phosphogluconate dehydrogenase (6-PGDH) is an enzyme of the pentose phosphate pathway. Evidence has appeared which suggests that the 6-PGDH protein sequence determined previously by direct analysis of the protein isolated from ovine liver is incorrect. Determining the enzyme's DNA sequence was considered to be the best way of solving the problem. In the first instance, a degenerate forward and a degenerate reverse primer were designed on the basis of the known protein sequence, and a partial-length cDNA clone was isolated from total sheep liver cDNA using the polymerase chain reaction. The clone encoded the expected part of the protein sequence. The clone was unsuccessfully used as a prime-cut probe to screen a sheep liver library and a bovine heart library. As a result, the polymerase chain reaction was utilized again to sucessfully generate a family of overlapping cDNA clones encoding a mature protein of 482 amino acids. The mature protein sequence encoded by the cDNA differs significantly from the sequence derived by direct analysis of the protein, but on closer examination the fundamental difference is caused by the incorrect placement of three enzyme fragments obtained by cyanogen bromide cleavage during the direct sequence analysis of the protein. Placing the fragments in the correct order results in the two sequences being virtually identical except for some minor amino acid changes between the amide and acid forms, and a small number of deletions and insertions.
\end{abstract}

\section{INTRODUCTION}

6-Phosphogluconate dehydrogenase [6-phospho-D-gluconate: NADP $^{+}$oxidoreductase (decarboxylating), EC1.1.1.44; 6-PGDH] is the third enzyme in the pentose phosphate pathway. It catalyses the oxidative decarboxylation of 6phosphogluconate to ribulose 5-phosphate, with release of $\mathrm{CO}_{2}$ and the reduction of $\mathrm{NADP}^{+}$. The enzyme isolated from sheep liver is a dimer of identical monomers with subunit $M_{\mathrm{r}}$ of approx. 47000 (Silverberg \& Dalziel, 1973). It has been crystallized and a $0.6 \mathrm{~nm}(6 \AA) X$-ray crystallographic structure determined (Adams et al., 1977), from which ligand-binding studies (Abdallah et al., 1979) indicated that the dinucleotide-binding site is dissimilar to $\mathrm{NADP}^{+}$-binding sites in all other $\mathrm{NADP}^{+}$dehydrogenases so far investigated. This contrasts with the conserved coenzyme-binding fold in $\mathrm{NAD}^{+}$dehydrogenases (Rossman et $a l ., 1975)$. Subsequently, the amino acid sequence of 6-PGDH was determined (Carne \& Walker, 1983) and used in the interpretation of the $0.26 \mathrm{~nm}(2.6 \AA)$ resolution structure (Adams et al., 1983). This structure shows that sheep 6-PGDH is $34 \%$ $\alpha$-helix and only $4 \% \beta$-sheet.

Amino acid sequence alignment of the sheep protein with the protein encoded by the Escherichia coli 6-PGDH gene (Nasoff $e t$ al., 1984) suggested that the sheep protein fragments obtained after cyanogen bromide cleavage of the enzyme during protein sequence determination were placed in the wrong order. In order to investigate this possibility and to allow a more detailed analysis of the nucleotide-binding fold, and for future assessment of ligand binding by using site-directed mutagenesis to produce specific mutants, the sheep 6-PGDH cDNA sequence has been determined. As a result of the failure of conventional cDNA library screening techniques to isolate sheep 6-PGDH cDNA clones, the polymerase chain reaction (PCR) (Saiki et al., 1988) has been used to generate the cDNA clones.

\section{MATERIALS AND METHODS}

\section{Isolation of RNA}

Total RNA was extracted from sheep livers according to the method of Chirgwin et al. (1979). As soon as possible after slaughter of the animal, small pieces of liver were frozen in liquid nitrogen. Then they were ground up under liquid nitrogen and homogenized for $30 \mathrm{~s}$ with a Polytron homogenizer in $4 \mathrm{M}$ guanidinium thiocyanate containing 50 mM-Tris, $\mathrm{pH} \mathrm{7.6}$, 12.5 mM-EDTA, $2 \%$ (w/v) sodium $N$-lauryl sarcosinate and $1 \%$ (v/v) 2-mercaptoethanol. After low-speed centrifugation, the supernatant was centrifuged through a cushion of caesium chloride $(15.7 \mathrm{M})$ at $180000 \mathrm{~g}$ for $18 \mathrm{~h}$. Typically, $1.5-3.0 \mathrm{mg}$ of total RNA was obtained from $3 \mathrm{~g}$ of frozen liver. Poly $(\mathrm{A})^{+}$ mRNA was prepared using ' $m A P$ ' paper (Amersham International) as follows. Total RNA ( $1 \mathrm{mg}$ in $1 \mathrm{ml}$ of $0.5 \mathrm{M}-\mathrm{NaCl})$ was incubated for $1 \mathrm{~h}$ with $4 \mathrm{~cm}^{3}$ of mAP paper cut into thin slices. Then the mAP paper was washed twice in $0.5 \mathrm{M}-\mathrm{NaCl}$ and once in $70 \%(\mathrm{v} / \mathrm{v})$ ethanol, and dried at room temperature. The mRNA was eluted from the mAP paper in distilled water at $70^{\circ} \mathrm{C}$ for $5 \mathrm{~min}$. Usually $1 \mathrm{mg}$ of total RNA yielded $15-25 \mu \mathrm{g}$ of $\operatorname{poly}(\mathrm{A})^{+}$mRNA.

\section{cDNA synthesis}

Total cDNA was synthesized from poly(A) ${ }^{+}$mRNA using the

\footnotetext{
Abbreviation used: 6-PDGH, 6-phosphogluconate dehydrogenase.

$\ddagger$ To whom correspondence should be sent.

\& Present address: The Wellcome Foundation Ltd., Langley Court, South Eden Road, Beckenham, Kent BR3 3BS, U.K.

The nucleotide sequence data reported will appear in the EMBL, GenBank and DDBJ Nucleotide Sequence Databases under the accession number X60195.
} 
cDNA Synthesis System Plus kit (Amersham International). First-strand cDNA was primed with oligo(dT) and synthesized at $42^{\circ} \mathrm{C}$ for $1 \mathrm{~h}$ using 20 units of reverse transcriptase $/ \mu \mathrm{g}$ of original mRNA (Anglian Biotechnology, Colchester, U.K.). Second-strand DNA was synthesized using 23.1 units of $E$. coli DNA polymerase I and 0.8 units of RNAase $\mathrm{H} / \mu \mathrm{g}$ of original mRNA. The ends of the double-stranded cDNA were trimmed to blunt ends using 2 units of T4 DNA polymerase $/ \mu \mathrm{g}$ of original mRNA.

\section{Circularization of total cDNA}

Approx. $100 \mathrm{ng}$ of total cDNA was end-repaired, first by incubation at room temperature for $30 \mathrm{~min}$ and then at $70^{\circ} \mathrm{C}$ for $10 \mathrm{~min}$, in $20 \mu \mathrm{l}$ of a solution containing $330 \mathrm{~mm}$-Tris/acetate, pH 7.5, $660 \mathrm{~mm}$-potassium acetate, $100 \mathrm{~mm}$-magnesium acetate, $30 \mathrm{~mm}$-spermidine, BSA fraction $\mathrm{V}(1 \mathrm{mg} / \mathrm{ml}), 1 \mathrm{~mm}$-dithiothreitol, $0.5 \mathrm{~mm}$ of each dNTP, T4 DNA polymerase ( 2 units; New England Biolabs, Beverly, MA, U.S.A.) and the Klenow fragment of DNA polymerase 1 (5 units; Boehringer Mannheim). Then the cDNA was self-ligated at $15^{\circ} \mathrm{C}$ for $15 \mathrm{~h}$ in the same solution diluted to $30 \mu \mathrm{l}$, to which had been added T4 DNA ligase (240 units; New England Biolabs), T4 RNA ligase (1.6 units; New England Biolabs) and 1 mM-rATP. The solution of the self-ligated cDNA $(10 \mu \mathrm{l})$ was used as template for a PCR.

\section{Radiolabelling of synthetic oligonucleotides}

Synthetic oligonucleotide probes were radiolabelled by incubation for $40 \mathrm{~min}$ at $37^{\circ} \mathrm{C}$ in a solution $(30 \mu \mathrm{l})$ comprising the oligonucleotide $(0.5 \mathrm{~mm}), 50 \mathrm{~mm}$-Tris $/ \mathrm{HCl}, \mathrm{pH} 7.6,10 \mathrm{~mm}$ $\mathrm{MgCl}_{2}$, $5 \mathrm{~mm}$-dithiothreitol, $0.1 \mathrm{~mm}$-spermidine, $0.1 \mathrm{~mm}$-EDTA, T4 polynucleotide kinase (5 units) and [ $\left.\gamma-{ }^{32} \mathrm{P}\right] \mathrm{ATP}(30 \mu \mathrm{Ci})$. The enzyme was inactivated by heating the solution at $70^{\circ} \mathrm{C}$ for $10 \mathrm{~min}$, and the radiolabelled oligonucleotide was purified by centrifugation through a $1 \mathrm{ml}$ column of Sephadex G-50 (Maniatis et al., 1982).

\section{Polymerase chain reaction}

The cDNA sequence of sheep liver 6-PGDH was amplified in five segments by means of the PCR (Saiki et al., 1988). The positions of primers (prefixed by PCR) and probes (prefixed by P) are indicated in Figs. 1 and 2. They were synthesized by phosphoramidite chemistry with the aid of Applied Biosystems $320 \mathrm{~B}$ and 380B oligonucleotide synthesizers, and purified on reverse-phase Sep-Pak columns (Waters Associates, Chester, Cheshire, U.K.) according to the manufacturer's instructions. Primers to be used in the forward direction of synthesis were made with the EcoRI linker TAGGAATTC at the $5^{\prime}$ end, and primers to be employed in the reverse direction of synthesis were made as the reversed and complemented sequence and with the $H$ indIII linker CGAAAGCTT at the $5^{\prime}$ ends. The amplification reaction was performed in a solution $(100 \mu \mathrm{l})$ containing $50 \mathrm{mM}$ $\mathrm{KCl}$; $10 \mathrm{~mm}-\mathrm{Tris} / \mathrm{HCl}, \mathrm{pH} 8.3,1.5 \mathrm{~mm}-\mathrm{MgCl}_{2}$, each dNTP $(200 \mu \mathrm{M})$, primers (concentration defined by experiment), cDNA (10 ng) and Thermus aquaticus DNA polymerase [ 3 units (unless otherwise stated); Perkin-Elmer-Cetus Corp., Beaconsfield, U.K.]. The reaction mixture was prepared without enzyme and preincubated at $96^{\circ} \mathrm{C}$ for $2.5 \mathrm{~min}$ followed by rapid cooling at $25^{\circ} \mathrm{C}$ for $1 \mathrm{~min}$. Then the enzyme was added and the reaction mixture was covered with mineral oil $(100 \mu \mathrm{l}$; Sigma Chemical Co., Poole, Dorset, U.K.). For amplifications of cDNA a Techne Programmable Dri-Block PHC-1 was used with a schedule of denaturation, annealing and then synthesis, followed by a single incubation at $70^{\circ} \mathrm{C}$ for $7 \mathrm{~min}$. Then the reaction mixture was allowed to cool to $40^{\circ} \mathrm{C}$. One-tenth of the products of the PCRs were fractionated by electrophoresis in a $1.4 \%$ high-gellingtemperature agarose gel and stained with ethidium bromide $(1 \mu \mathrm{g} / \mathrm{ml})$. Also, the fractionated reaction products were transferred from the gel to a Hybond- $\mathrm{N}$ membrane (Amersham International) according to Southern (1975). Prehybridization was carried out at $35^{\circ} \mathrm{C}$ for $2 \mathrm{~h}$ in a solution containing $6 \times \mathrm{SSC}$ (comprising $0.90 \mathrm{M}-\mathrm{NaCl}$ and $0.09 \mathrm{M}$-sodium citrate), $5 \times$ Denhardt's solution [comprising poly(vinyl pyrrolidone), BSA fraction V and Ficoll, all at $1 \mathrm{mg} / \mathrm{ml}$, $0.5 \%$ (w/v) SDS and sonicated salmon sperm DNA $(20 \mu \mathrm{g} / \mathrm{ml})$. Hydridization was performed overnight at $35^{\circ} \mathrm{C}$ in the same solution containing the appropriate radiolabelled probe. The membranes were washed twice for $10 \mathrm{~min}$ in a solution containing $2 \times \mathrm{SSC}$ and $0.5 \%$ (w/v) SDS and autoradiographed with preflashed film (Fuji RX 100) at $-70^{\circ} \mathrm{C}$. Hybridizing bands were recovered from agarose gels and were purified using a Geneclean kit (Bio 101, La Jolla, CA, U.S.A.) according to the manufacturer's instructions. Some products were then re-amplified as in the initial reactions, and analysed and purified as above. Purified products $(12 \mu \mathrm{l})$ were digested for $1 \mathrm{~h}$ at $37^{\circ} \mathrm{C}$ in a solution containing $1 \mathrm{~mm}$ -

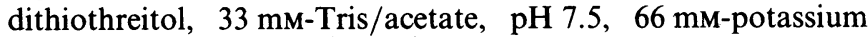

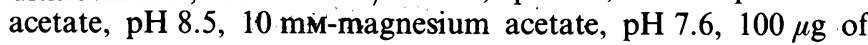
BSA $/ \mathrm{ml}, 3 \mathrm{~mm}$-spermidine and the restriction enzymes EcoRI (10 units) and HindIII (10 units). Then the enzymes were inactivated by heating the solution at $70^{\circ} \mathrm{C}$ for $20 \mathrm{~min}$, and the products of the PCR were ligated to the vectors M13mp19 and M13mp18, which had been digested with the same restriction enzymes. These recombinations were transfected into $E$. coli TG1, and the cells were grown up on agar plates in the presence of isopropyl $\beta$-D-thiogalactopyranoside and 5-bromo-4-chloro3 -indolyl- $\beta$-D-galactopyranoside. The resultant mini-libraries were screened by placing nitrocellulose filters on each plate for $1 \mathrm{~min}$ and then treating the filters according to the method of Benton \& Davis (1977). The filters were prehybridized for $1 \mathrm{~h}$ at $55^{\circ} \mathrm{C}$ with a solution comprising $6 \times$ SSC, $5 \times$ Denhardt's solution, $0.5 \%(\mathrm{w} / \mathrm{v})$ SDS and sonicated salmon sperm DNA $(50 \mu \mathrm{g} / \mathrm{ml})$. Hybridization was performed overnight in the same solution containing the radiolabelled probe. The filters were washed for $2 \times 10 \mathrm{~min}$ with $2 \times \mathrm{SSC} / 0.5 \%$ (w/v) SDS and autoradiographed as before. After a $3 \mathrm{~h}$ exposure, positively hybridizing recombinants could be detected. They were subjected to DNA sequence analysis. To obtain the $3^{\prime}$ and $5^{\prime}$ ends of the sheep liver 6-PGDH cDNA, circularized total cDNA $(10 \mu \mathrm{l})$ was used as the template for PCR. The forward primer, PCR-F5, and reverse primer, PCR-R5, were derived from the cDNA data obtained in the previous experiment. The experiment was based upon the 'booster' PCR (Ruano et al., 1989). Initially the primer concentrations in the reaction were both $2.5 \mathrm{pm}$ and the PCR schedule 5(a)i (see Fig. 1) was followed. A final single incubation of the reaction, of $70^{\circ} \mathrm{C}$ for $7 \mathrm{~min}$, was not performed. Both primers were boosted to $0.1 \mu \mathrm{m}$ and the PCR was continued according to schedule 5(a)ii (see Fig. 1). The products of the PCR were analysed as above.

\section{DNA sequencing}

DNA sequence analysis was carried out by the method of Sanger et al. (1977), as modified by Biggin et al. (1983). Synthetic oligonucleotide primers of 17 bases in length were used to sequence all isolates completely in both senses of the DNA. Where sequences had been cloned in one sense of the DNA only, the clone was turned around (Bankier et al., 1987). Compressions in DNA sequences were resolved by the substitution of deoxy-7. deazaguanosine triphosphate (Mizusawa et al., 1986) in place of dGTP in the sequencing reaction mixtures. Data were compiled and analysed with the aid of the computer programs DBUTIL (Staden, 1982) and ANALYSEQ (Staden, 1984). 


\section{RESULTS AND DISCUSSION}

\section{Isolation of cDNA clones encoding sheep liver 6-PGDH}

In experiments preceding those described in this paper, several unsuccessful attempts have been made to isolate cDNA clones for 6-PGDH (D. O'N. Somers, J. E. Walker \& M. J. Adams, unpublished work) from a sheep cDNA library cloned in a bacteriophage $\lambda$ vector (S. M. Medd \& J. E. Walker, unpublished work) and from a bovine plasmid library (Gay \& Walker, 1985a). In initial experiments on the sheep library, two degenerate synthetic oligonucleotides of 17 nucleotides in length, based upon the amino acid sequence of the protein (Carne \& Walker, 1983), were employed as hybridization probes. These were TEFGWT and NKEAWP, amino acid residues 90-95 and 236-241 respectively. The degeneracies of the corresponding oligonucleotides were 64 and 32. In contrast, other experiments using prime-cut probes (Farrell et al., 1983) to isolate cDNAs for mitochondrial ATP synthase from the sheep library had been successful (S. M. Medd \& J. E. Walker, unpublished work). Therefore a similar approach was tried in which an initial clone was generated by amplifying a partial sheep 6-PGDH cDNA sequence, using the PCR reaction. It was intended that this cDNA could then be used as a prime-cut probe to isolate more extensive clones in the cDNA library. cDNAs for the $\delta$-subunit of bovine ATP synthase, for example, have been isolated in this way (Runswick et al., 1990).

Expt. 1. The initial experiment was designed to amplify a part of the sheep liver 6-PGDH cDNA encoding a part of the protein sequence of the enzyme (see the Materials and methods section for more details). The forward primer PCR-F1 and reverse primer PCR-R1 were used (see Figs. 1 and 2). PCR-F1 was designed on the basis of amino acid residues 236-241 of the sheep liver 6-PGDH protein sequence (Carne \& Walker, 1983) and contained 32 different sequences. PCR-R1 was designed on the basis of amino acid residues 336-341 of the protein sequence and had a degeneracy of 64 . The primer concentrations in the amplification reaction were $4 \mathrm{~mm}-\mathrm{PCR}-\mathrm{F} 1$ and $8 \mathrm{~mm}-\mathrm{PCR}-\mathrm{R} 1$, and 6 units of $T$. aquaticus DNA polymerase were used. No band of about $300 \mathrm{bp}$ was detected by ethidium bromide staining of the fractionated products of the PCR. However, probe P-F1, containing 32 different synthetic oligonucleotides and designed from amino acid residues 281-286 of the sheep liver 6-PGDH protein sequence (Carne \& Walker, 1983), hybridized strongly with a product of about $300 \mathrm{bp}$ present in the products of the $\mathrm{PCR}$. The isolated and purified product $(0.5 \mathrm{ml})$ was re-amplified in a reaction mixture containing the forward and reverse primers, each at a concentration of $4 \mathrm{~mm}$, and no other cDNA. The PCR schedule was repeated. The products of the PCR were analysed as before, and were found to contain a doublet at about $300 \mathrm{bp}$ in an agarose gel stained with ethidium bromide. One band, or possibly both bands, hybridized strongly with the radiolabelled probe P-F1 (see Fig. 1). About $75 \%$ of the products of the PCR were fractionated by gel electrophoresis and the doublet was recovered. A mini-library of the products in the doublet was screened with the radiolabelled probe P-F1. This resulted in several positively hybridizing recombinants being isolated for DNA sequence analysis, which showed them to code for the amino acids $242-335$ of the sheep 6-PGDH protein sequence (Carne \& Walker, 1983), although amino acids 295 and 296 were absent. Several unsuccessful attempts were made to screen the sheep cDNA library (S. M. Medd, J. E. Walker \& R. D. Jolly, unpublished work) and the bovine cDNA library (Gay \& Walker, $1985 a$ ) using the PCR-derived partial cDNA sequence as a prime-cut probe. These results were particularly surprising because a unique probe was being used to screen the libraries. Degenerate oligonucleotide probes had been used successfully to

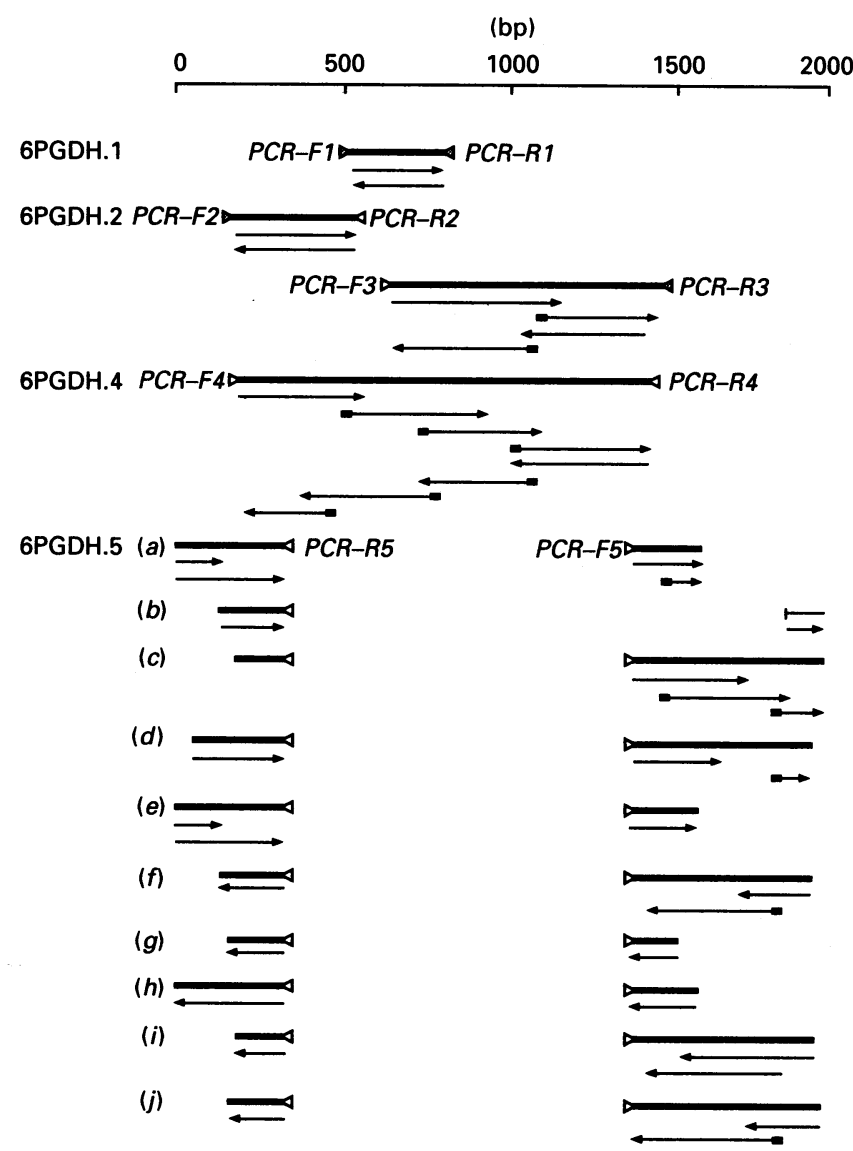

Fig. 1. Sequence analysis of cDNA clones encoding sheep liver 6-PGDH

The name of each cDNA clone is shown on the left-hand side of the diagram and the appended number refers to the number of the experiment. The cDNAs were generated by the PCR and their extents are shown by thick lines. Clones 6PGDH.5 $(a)-(j)$ are the unique clones obtained in Expt. 5. Each clone [except 6PGDH.5(b)] is flanked by a degenerate forward primer $(\$)$, a degenerate reverse primer $(\triangle)$, a unique forward primer $(D)$ or a unique reverse primer $(\triangleleft)$. The horizontal arrows represent the DNA sequences that were determined, and synthetic oligonucleotide primers employed in the sequencing reactions are denoted by black boxes. The scale is in base pairs.

isolate cDNAs in the bovine library for subunits of ATP synthase (Gay \& Walker, 1985b; Walker et al., 1985, 1987, 1989; Viñas et al., 1989), for mitochondrial transport proteins (Runswick et al., 1987; Powell et al., 1989) and for components of mitochondrial complex I (Fearnley et al., 1989; Pilkington \& Walker, 1989; Runswick et al., 1989). Therefore it seemed very possible that cDNAs for 6-PGDH were poorly represented, or even absent from these libraries.

In order to extend the partial cDNA sequence to regions corresponding to the $3^{\prime}$ and $5^{\prime}$ extremities of the mRNA, a number of other possible PCR strategies (besides screening cDNA libraries) were tried. The sequence could be extended up to the $3^{\prime}$ poly(A) sequence by using a unique forward primer based on the known sequence and a reverse poly $(T)$ primer. This first strategy was unsuccessful (D. O'N. Somers, S. M. Medd, J. E. Walker \& M. J. Adams, unpublished work), although subsequently it has been used successfully in cloning other proteins. The second strategy was to extend up the $3^{\prime}$ and $5^{\prime}$ protein coding regions of the mRNA as described in Expt. 2.

Expt. 2. A segment of the sheep liver 6-PGDH cDNA was 
$-1$ 1 A A D I A I I G L A V M G O N

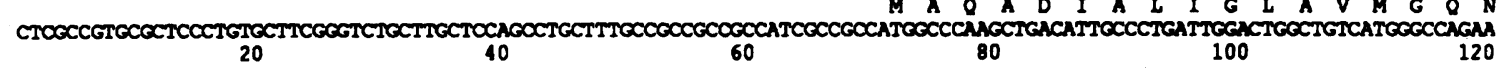

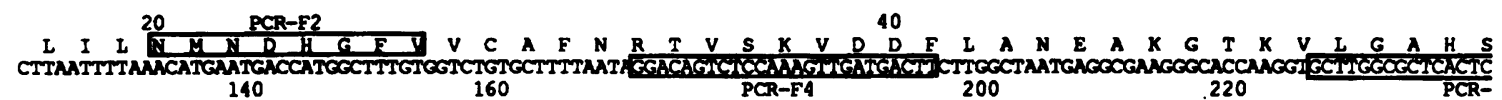

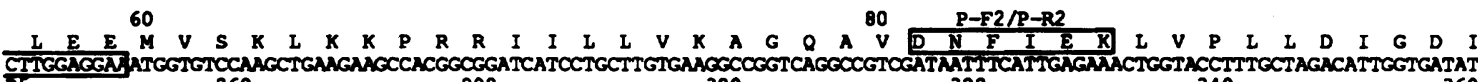

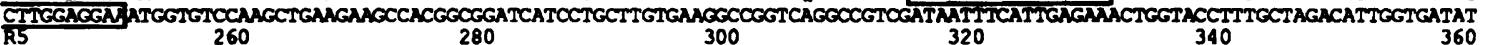

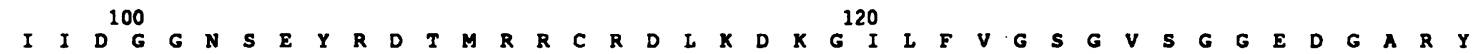

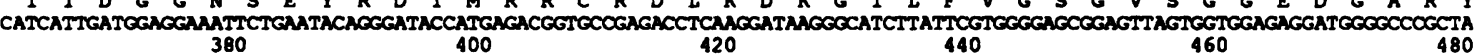

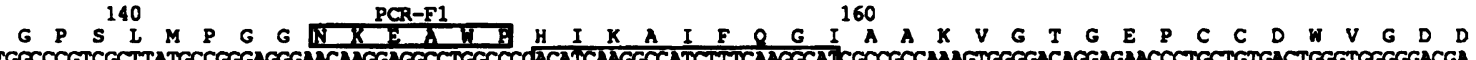

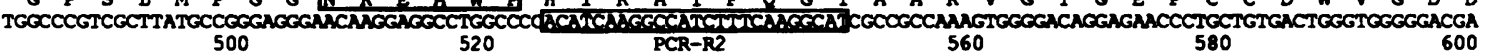

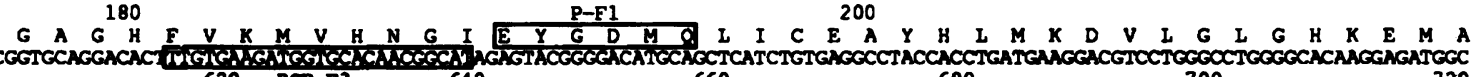

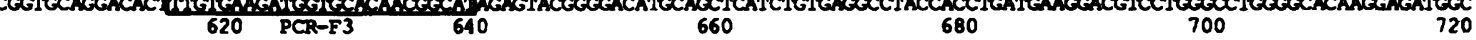

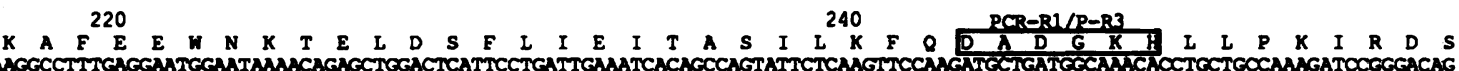

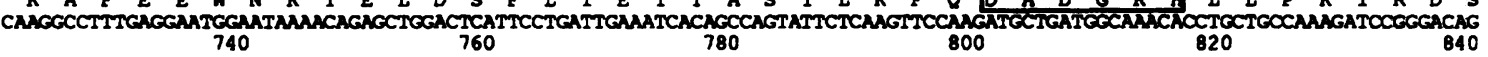

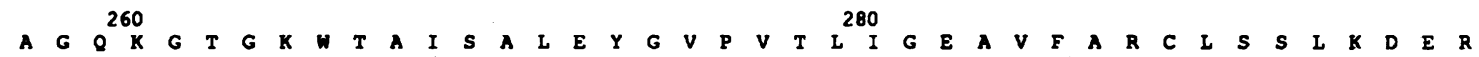

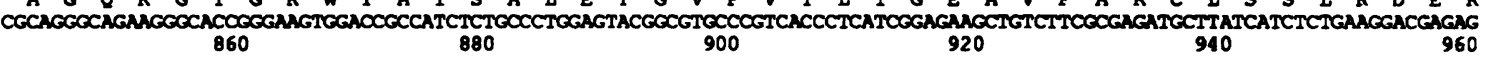

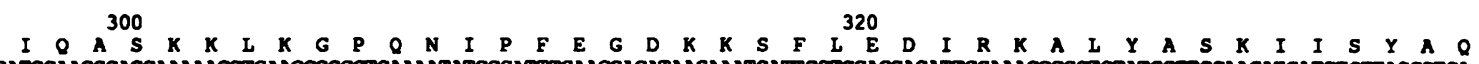

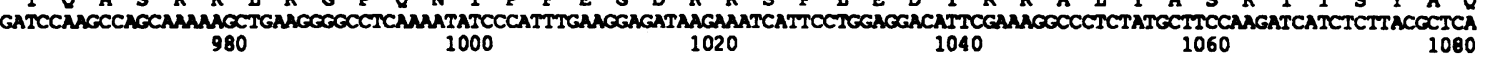

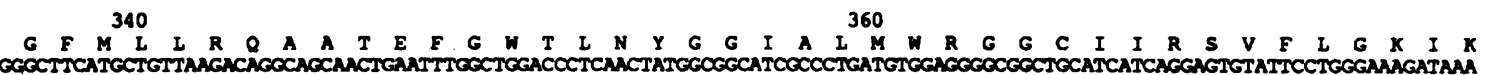

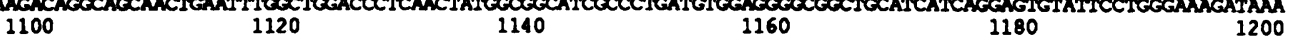

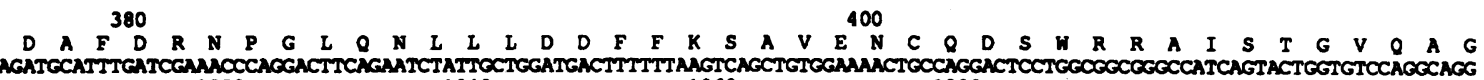
$1220 \quad 1240 \quad 1260 \quad 1280 \quad 1300 \quad 1320$

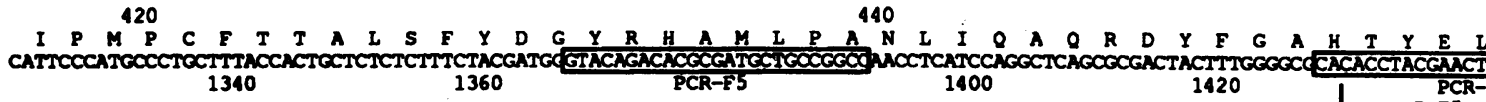

$K_{\mathrm{P}}^{460}\left[\begin{array}{l}P C B-R 3 \\ \hline\end{array}\right.$

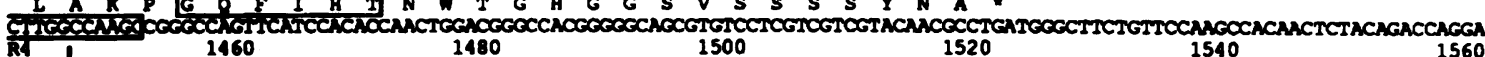

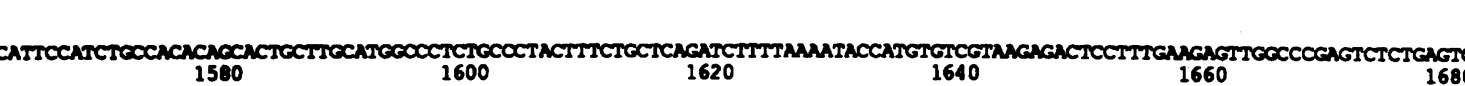

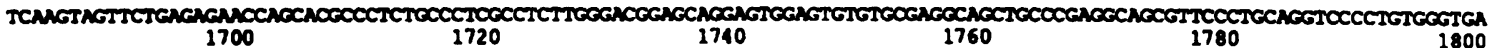

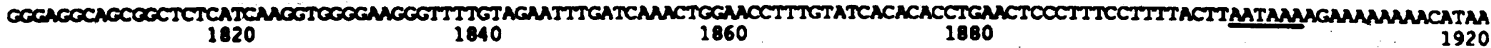

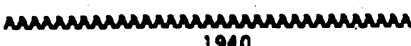

1940

Fig. 2. DNA sequence of a family of overlapping cDNAs encoding sheep liver 6-PGDH

The protein sequence is numbered from 1 to 482 . The initiator methionine (numbered -1 ) is not present in the mature protein, which has $N$ terminal $N$-acetylalanine at position 1 . The nucleic acid sequence is numbered from 1 to 1953 . The primers (prefixed by PCR) and oligonucleotide probes (prefixed by $\mathbf{P}$ ) are based on protein sequences that are boxed. The cDNA sequences used for making unique primers for DNA sequencing are also boxed. A potential signal for polyadenylation of mRNA is underlined. 
amplified, the $5^{\prime}$ end of which was close to a part of the translated cDNA sequence that was in doubt. The amplified segment would also overlap the segment amplified in Expt. 1. A forward primer, PCR-F2, was designed from amino acid residues 111-118 of the sheep liver 6-PGDH protein sequence (Carne \& Walker, 1983). It comprised 128 different sequences. The reverse primer, PCR$\mathrm{R} 2$, was a unique sequence, since it was designed from the cDNA segment of Expt. 1. The PCR contained primer concentrations of $2 \mathrm{mM}-\mathrm{PCR}-\mathrm{F} 2$ and $1 \mathrm{~mm}-\mathrm{PCR}-\mathrm{R} 2$, and analysis of the PCR products was performed as described in Exp. 1 (see the Materials and methods section for more details). A visible band of about $450 \mathrm{bp}$ was seen after gel electrophoresis, and a radiolabelled synthetic oligonucleotide prober (P-F2) with a complexity of 48 , designed from amino acid residues 172-177 of the sheep liver protein sequence (Carne \& Walker, 1983), hybridized strongly with this band. The band was recovered using $60 \%$ of the products of the PCR, as in Expt. 1. A mini-library of the products in the band was screened as in Expt. 1 using the radiolabelled synthetic oligonucleotides P-F2 and P-R2 (reverse and complement of P-F2) for the recombinants of M13mp19 and M13mp18 respectively. DNA sequence analysis of positively hybridizing recombinants showed them to code for amino acids 119-241 of sheep liver 6-PGDH (Carne \& Walker, 1983).

Expt. 3. A segment of the sheep liver 6-PGDH cDNA was amplified which overlapped the segment produced in Expt. 1 and which had a $3^{\prime}$ end corresponding to a sequence coding for protein near to the $C$-terminal end of the sheep liver protein sequence (Carne \& Walker, 1983). The forward primer PCR-F3 was designed from the cDNA sequence derived in Expt. 1, and the reverse primer PCR-R3 was designed from amino acid residues $457-462$ of the sheep liver protein sequence (Carne \& Walker, 1983). It contained 384 different sequences. As in Expt. 1 , amplifications and re-amplifications were performed (see the Materials and methods section and Fig. 1 for more details), but using PCR schedules $3(a)$ and $3(b)$ respectively (Fig. 1) and primer concentrations of $1 \mathrm{~mm}-\mathrm{PCR}-\mathrm{F} 3$ and $2 \mathrm{mM}-\mathrm{PCR}-\mathrm{R} 3$. A band of about $900 \mathrm{bp}$ was isolated which hybridized strongly to the radiolabelled synthetic oligonucleotide probe P-F1. A minilibrary of this product was screened using radiolabelled P-F1 and P-R3 (reverse and complement of P-F1). DNA sequence analysis showed positively hybridizing recombinants to code for a segment of sheep liver 6-PGDH between amino acids 280 and 457 (Carne \& Walker, 1983), but which was longer than expected due to an insertion of about 100 amino acids.

Expt. 4. Using the data from the three segments of sheep liver 6-PGDH cDNA, a segment of cDNA covering their combined length was amplified and re-amplified according to PCR schedules $4(a)$ and $4(b)$ respectively (Fig. 1). The forward primer PCR-F4 was derived from the cDNA segment of Expt. 2, and the reverse primer PCR-R4 was derived from the CDNA segment of Expt. 3. The procedure of Expt. 1 was followed (see the Materials and methods section for more details) using primer concentrations of 1 mM-PCR-F4 and 2 mm-PCR-R4. A band of about $1300 \mathrm{bp}$ was isolated which hybridized strongly to the radiolabelled synthetic oligonucleotide probe P-F1. DNA sequence analysis of this product (without screening a mini-library) showed it to code for a segment of sheep liver 6-PGDH between amino acids 133 and 447 (Carne \& Walker, 1983), but with the same insertion of about 100 amino acids that was also encoded by the partial sheep liver 6-PGDH cDNA isolated in Expt. 3. The third strategy of the PCR was to obtain both $3^{\prime}$ and $5^{\prime}$ extremities of the 6-PGDH mRNA by circularizing the cDNA by ligating its $3^{\prime}$ and $5^{\prime}$ ends together, and then amplifying the unknown region across the join by using unique forward and reverse primers designed from the known sequence. This approach has been used successfully in investigating sheep cDNAs of the dicycloCDNA translation AOADIALIGLAWMGONLILNANDHGFWCAFNRTVSKVDDFLANEAKGTKVLGAHSLEEMY CNBr fragment :::: : :: :: : : :::: : : : : : : : : : : : : : : : : : : : : : : : : : : : : : : : : : :

CDNA translation VSKLKKPRRI ILLVKAGGAVDNF IEKLVPLLDIGDIIIDGGNSEYRDTMRRCRDLKDKGI

CDNA translation VSKLKKPRRI ILLVKAGQAVDNF IEKLVPLLDIGDIIIDGGNSEYRDTMRRCRDLKDKGI

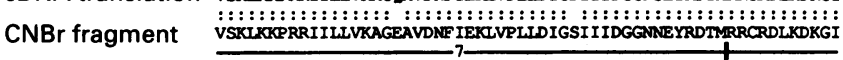
CDNA translation IFVGSGVSGGEDGARYGPSIMPGGAGPANPHTXAIFCGIAAKVGTGEPCCDWVGDDGAGH

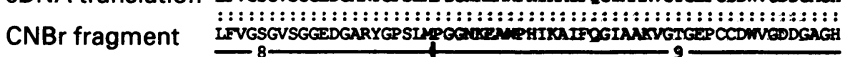

CDNA translation FVKONHNGIEYGDMOLICEAYHL--MKDVLGLGAKEMAKCFFEDMXKTEIDSFLIEITASILK

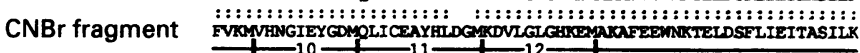
CDNA translation FODADGKHLIPKIRDSAGOKGTGKMTAISAIEYGVPVTLIGEAVIARCISSIKDERIOAS

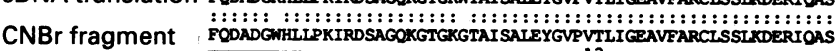
CDNA translation KKCKKPQNIPFEGDKKSFLEDIRKALYASKIISYAOGFRLLROANTEFGWTLNYGGIALM

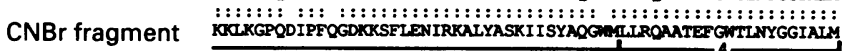

CDNA translation WRGGCIIRSVFIGKIKDAFDRNPGLONLILDDFFKSAVENCQDSWRRAISTGVOAGIPMP

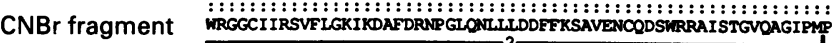

CDNA translation CFTTALSFYDGYRHAMLPANLIQAORDYFGAHTYELLAKPGOFIHTN--WTGHGGSVSSSSY

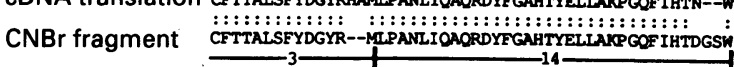

cDNA translation NA

Fig. 3. Alignment of sequences of $\mathrm{CNBr}$ fragments of sheep liver 6-PGDH obtained by direct sequence analysis with the protein sequence obtained by translation of the cDNA sequence

The protein sequences of peptides are taken from Carne \& Walker (1983), and the cDNA sequence was determined in the present work.

hexylcarbodi-imide-reactive subunit of ATP synthase (S. M. Medd \& J. E. Walker, unpublished work).

Expt. 5. After performing the PCRs and subsequent analysis of their products (see the Materials and methods section for full details), a broad band of products of about $650-800 \mathrm{bp}$ in length was seen which hybridized with the radiolabelled primer PCR-F4 (at a hybridization temperature of $40^{\circ} \mathrm{C}$ ). The products in this band were isolated, and $1 \mathrm{ml}$ of the reaction products was reamplificated according to PCR schedule 5(b) (Fig. 1). The primer concentrations were both $1 \mathrm{~mm}$. A broad band hybridized strongly to the radiolabelled primer PCR-F4. About $80 \%$ of the products of the PCR were purified using a GENECLEAN kit. A mini-library was made as above, and the $\mathrm{M} 13 \mathrm{mp} 19$ recombinants were screened at a hybridization temperature of $40^{\circ} \mathrm{C}$ using the radiolabelled primer PCR-F4 on one set of filters and the radiolabelled probe P-F5 on duplicate filters that had been placed on the agar plates for $2 \mathrm{~min}$. M13mp18 recombinants were screend with the radiolabelled primer PCR-R4 (also at $40{ }^{\circ} \mathrm{C}$ ). The filters were washed for $2 \times 15 \mathrm{~min}$. Autoradiography revealed several positively hybridizing recombinants which were analysed by DNA sequence analysis, and ten were found to be 


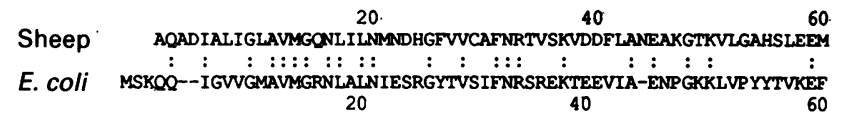

20

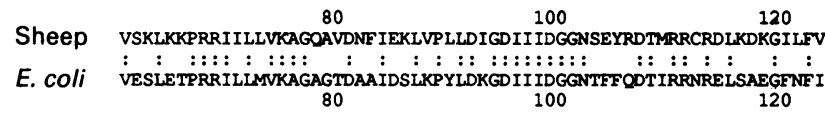

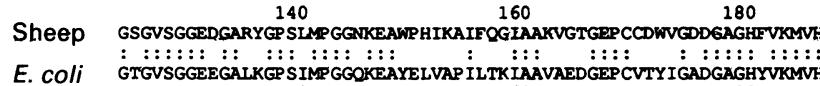
140
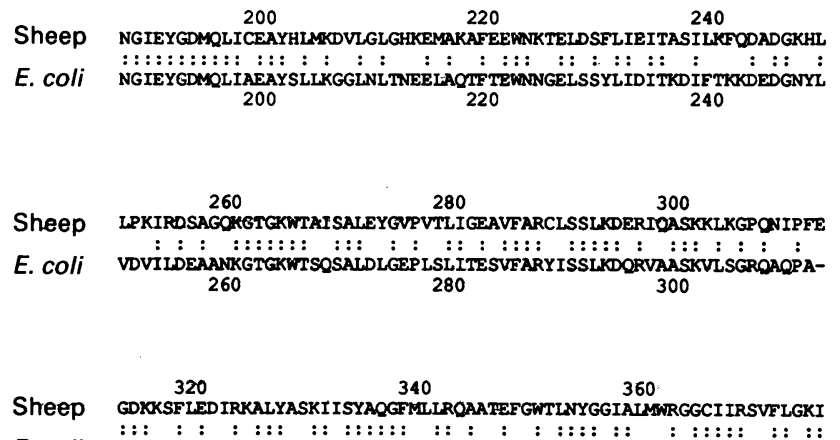

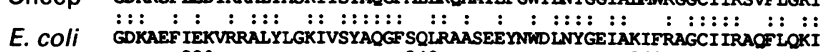
320 340 360
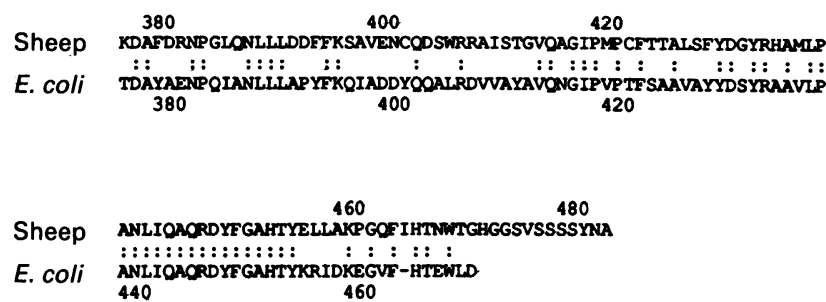

Fig. 4. Alignment of the protein sequences of $E$. coli and sheep liver 6-PGDH

The bacterial and sheep sequences are taken from Nasoff et al. (1984) and the present work respectively. The alignment was produced with the aid of the computer program PRTALN (Wilbur \& Lipman, 1983).

unique cDNAs that encode the sheep liver 6-PGDH $N$-terminus and $C$-terminus and contain varying lengths of $3^{\prime}$ and $5^{\prime}$ untranslated sequence. The $3^{\prime}$ and $5^{\prime}$ ligation point was derived from the clones that had a poly(A) tail.

\section{cDNA sequence encoding sheep liver 6-PGDH}

The cDNA sequence presented in Fig. 2, compiled from clones 6PGDH.1-6PGDH.5 $(j)$ (shown in Fig. 1), is 1953 nucleotides in length. Clone 6PGDH.5(b) was much shorter than expected, missing the nucleotide sequence from the forward primer up to a GAATTT site (nucleotides 1366-1842). This site (nucleotides 1842-1847) was probably cleaved by the restriction enzyme EcoRI during restriction enzyme digestion of the product prior to ligation into the vector M13mp19. Restriction enzymes have been observed to cleave nucleotide sequences which are similar but not identical to their defined recognition sequence. This process has been termed 'star' activity (Polisky et al., 1975).

The cDNA sequence encodes a protein sequence that is 482 amino acids long, with an $M_{\mathrm{r}}$ of 52839 . The cDNA sequence has

a $\mathrm{C}+\mathrm{G}$ content of $53.1 \%$, and the dinucleotide sequence $\mathrm{CpG}$ is distributed throughout the cDNA sequence, with the highest concentrations in the $5^{\prime}$ non-coding region. This dinucleotide sequence has been found to be clustered in mammalian genomes in CpG-rich islands (Bird, 1986), which are usually associated with the $5^{\prime}$ regions of genes and probably influence their expression. The $3^{\prime}$ non-coding region is rather extensive and has a potential signal for addition of poly(A) (see Fig. 2), with polyadenylation occurring after nucleotide 1918. Clones 6PGDH.5(b) and 6PGDH.5 $(j)$ had cytosine instead of adenine at positions 1920, 1922 and 1924 of the cDNA sequence poly(A) tail. There were regarded as PCR or sequencing artifacts, since clone 6PGDH.5(i) indicated adenosine at positions 1920, 1922 and 1924 in its poly(A).

\section{Comparison of the protein sequences encoded by the sheep liver 6-PGDH cDNA and the $E$. coli 6-PGDH gene}

A comparison of the 6-PGDH protein sequence (Carne \& Walker, 1983) with the protein sequence encoded by the sheep liver cDNA sequence determined in this present work indicates that the most probable explanation for the difference between them is due to the misalignment of the peptides (CB1-14) resulting primarily from the cyanogen bromide cleavage of the $S-\left[{ }^{14} \mathrm{C}\right]$ carboxymethylated enzyme during the protein sequence determination (Carne \& Walker, 1983). Re-alignment of these peptides, such that $\mathrm{CB} 2, \mathrm{CB} 3$ and $\mathrm{CB} 4$ are inserted between $\mathrm{CB} 13$ and $\mathrm{CB} 14$ in the order $\mathrm{CB} 4, \mathrm{CB} 2$ and $\mathrm{CB} 3$, produces a protein that is fundamentally the same as that encoded by the cDNA sequence, with only minor differences (Fig. 3). One problem has not yet been resolved. In protein sequencing experiments, no evidence was found of the sequence following tryptophan-468, and the cyanogen bromide fragment covering this region terminated at this residue (Carne \& Walker, 1983). The X-ray structure does not resolve this point either, and residues beyond 469 are poorly ordered in the crystals (Adams et al., 1991). Determination of the $M_{\mathrm{r}}$ of the protein by electrospray mass spectrometry should decide the matter finally.

The protein sequence encoded by the sheep liver 6-PGDH cDNA sequence has over $50 \%$ similarity with the protein encoded by the E. coli 6-PGDH gene (Nasoff et al., 1984) (Fig. 4). The sequence similarity is evenly distributed and tends to reinforce the premise that the 6-PGDH sheep liver protein sequence previously described (Carne \& Walker, 1983) is incorrect.

Armed with the corrected sequence, a high resolution structure of ovine 6-PDGH to $0.25 \mathrm{~nm}(2.5 \AA)$ resolution has been determined recently (Adams et al., 1991).

\section{Note added in proof (received 3 November 1992)}

It has not been possible so far to measure the molecular mass of 6-phosphonate dehydrogenase by electrospray mass spectrometry. However, $\mathrm{X}$-ray crystallographic studies suggest that at least part of the $C$-terminal extension is present in the isolated protein.

D. O'N. S. was supported by an E.P.A. Cephalosporin Trust Research Studentship. S.M.M. was supported by a M.R.C. Research Studentship.

\section{REFERENCES}

Abadallah, M. A., Adams, M. J., Archibald, I. G., Biellmann, J.-F., Helliwell, J. R. \& Jenkins, S. E. (1979) Eur. J. Biochem. 98, 121-130 Adams, M. J., Helliwell, J. R. \& Bugg, C. E. (1977) J. Mol. Biol. 112, 183-197

Adams, M. F., Archibald, I. G., Bugg, C. E., Carne, A., Gover, S., Helliwell, J. R., Pickersgill, R. W. \& White, S. W. (1983) EMBO J. 2, 1009-1014 
Adams, M. J., Gover, S., Leaback, R., Phillips, C. \& Somers, D. O'N. (1991) Acta Crystallogr. B47, 817-820

Bankier, A. T., Weston, K. M. \& Barrell, B. G. (1987) Methods Enzymol. 155, 51-93

Benton, W. D. \& Davis, R. W. (1977) Science 196, 180-182

Biggin, M. D., Gibson, T. J. \& Hong, G. F. (1983) Proc. Natl. Acad. Sci. U.S.A. 80, 3963-3965

Bird, A. P. (1986) Nature (London) 321, 209-213

Carne, A. \& Walker, J. E. (1983) J. Biol. Chem. 258, 12895-12906

Chirgwin, J. M., Przybyla, A. E., MacDonald, R. J. \& Rutter, W. J. (1979) Biochemistry 18, 5294-5299

Farrell, P. J., Deininger, P. L., Bankier, A. \& Barrell, B. G. (1983) Proc. Natl. Acad. Sci. U.S.A. 80, 1565-1569

Fearnley, I. M., Runswick, M. J. \& Walker, J. E. (1989) EMBO J. 8, 665-672

Gay, N. J. \& Walker, J. E. (1985a) Biochem. J. 225, 707-712

Gay, N. J. \& Walker, J. E. (1985b) EMBO. J. 4, 3519-3524

Maniatis, T., Frisch, E. F. \& Sambrook, J. (1982) Molecular Cloning: a Laboratory Manual, Cold Spring Harbor Laboratory Press, Cold Spring Harbor

Mizusawa, S., Nishimura, S. \& Seela, F. (1986) Nucleic Acids Res. 14, 1319-1324

Nasoff, M. S., Baker, H. V. \& Wolfe R. E., Jr. (1984) Gene 27, 253-264 Pilkington, S. J. \& Wạlker, J. E...(1989) Biochemistry 28, 3257-3264

Polisky, B., Green, P., Garfin, D. E., McCarthy, B. J., Goodman, H. M. \& Boyer, H. W. (1975) Proc. Natl. Acad. Sci. U.S.A. 72, 3310-3314

Powell, S. J., Medd, S. M., Runswick, M. J. \& Walker, J. E. (1989) Biochemistry 28, 866-873

Received 28 August 1991; accepted 25 September 1991
Rossman, M. G., Liljas, A., Branden, C. I. \& Banaszak, L. J. (1975) Enzymes 3rd ed. 11, 61-102

Ruano, G., Fenton, W. \& Kidd, K. K. (1989) Nucleic Acids Res. 17, 5407

Runswick, M. J., Powell, S. J., Nyren, P. \& Walker, J. E. (1987) EMBO J. 6, 1367-1373

Runswick, M. J., Gennis, R. B., Fearnley, I. M. \& Walker, J. E. (1989) Biochemistry 28, 9452-9459

Runswick, M. J., Medd, S. M. \& Walker, J. E. (1990) Biochem. J. 266, $421-426$

Saiki, R. K., Gelfand, D. H., Stoffel, S., Scharf, S. J., Higuchi, R. G., Horn, G. T., Mullis, K. B. \& Erlich, H. A. (1988) Scienee 239, 487-491

Sanger, F., Nicklen, S. \& Coulson, A. R. (1977) Proc. Natl. Acad. Sci. U.S.A. 74, 5463-5467

Silverberg, M. \& Dalziel, K. (1973) Eur. J. Biochem. 38, 229-238

Southern, E. M. (1975) J. Mol. Biol. 98, 503-517

Staden, R. (1982) Nucleic Acids Res. 10, 4731-4751

Staden, R. (1984) Nucleic Acids Res. 12, 521-538

Viñas, O., Powell, S. J., Runswick, M. J., Iacobazzi, V. \& Walker, J. E. (1989) Biochem. J. 265, 321-326

Walker, J. E., Fearnley, I. M., Gay, N. J., Gibson, B. W., Northrop, F. D., Powell, S. J., Runswick, M. J., Saraste, M. \& Tybulewicz, V. L. J. (1985) J. Mol. Biol. 184, 677-701

Walker, J. E., Runswick, M. J. \& Poulter, L. (1987) J. Mol. Biol. 197, $89-100$

Walker, J. E., Powell, S. J., Viñas, O. \& Runswick, M. J. (1989) Biochemistry 28, 4702-4708

Wilbur, W. J. \& Lipman, D. J. (1983) Proc. Natl. Acad. Sci. U.S.A. 80, 726-730 